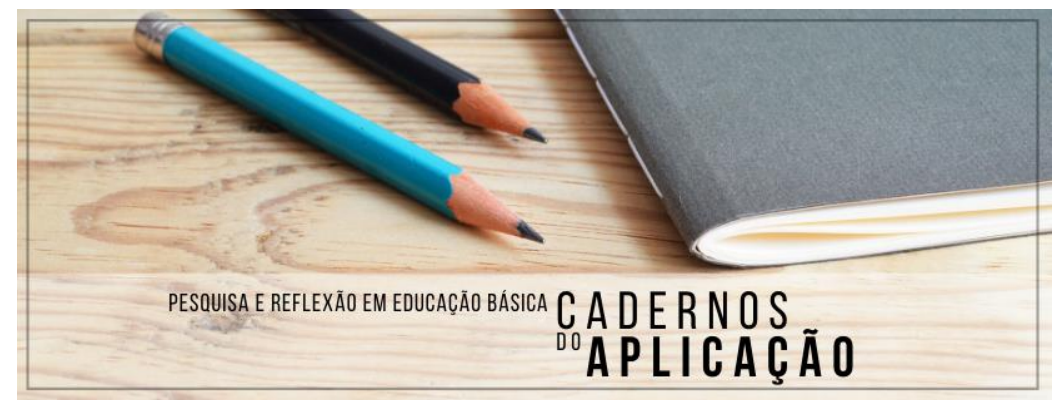

Cadernos do Aplicação

https://seer.ufrgs.br/CadernosdoAplicacao

Publicação Ahead of Print

ISSN 2595-4377 (online)

Porto Alegre | jul-dez. 2021 | v.34 | n.2

\title{
Projeto PIBID e suas tessituras: reflexões sobre formação docente, Educação Especial e Matemática
}

\author{
Mayara Costa da Silva ${ }^{1}$ \\ Thaylles Leal da Rosa ${ }^{2}$ \\ Rodrigo Sychocki da Silva ${ }^{3}$
}

\begin{abstract}
Resumo: $O$ presente texto tem como objetivo analisar a constituição de um processo formativo pautado na experiência docente, com foco no espaço de articulação entre uma professora de Educação Especial e professores da área de Matemática no desenvolvimento de uma proposta vinculada ao Programa Institucional de Bolsas de Iniciação à Docência (PIBID). A proposta pautou-se na ação pedagógica de um bolsista do programa em questão, graduando do curso de Licenciatura em Matemática junto ao Atendimento Educacional Especializado. Diante disso, com base em uma metodologia de abordagem qualitativa, realizou-se uma revisão de literatura acerca da temática e uma análise da experiência em questão, a partir da observação e da análise documental dos relatórios e registros. Os dados foram lidos e interpretados a partir do referencial teórico relacionado ao pensamento sistêmico, bem como, à luz das ideias de estudiosos do campo da formação docente. A partir disso, torna-se possível afirmar que a formação docente decorrente da experiência analisada no projeto se constituiu, de forma prioritária, a partir da articulação entre os professores envolvidos, por meio de um trabalho em rede, com espaço para diálogo, planejamento em conjunto e trocas de experiências envolvidas no processo pedagógico.
\end{abstract}

Palavras-chave: Formação docente. Educação Especial. Matemática. Inclusão escolar.

\section{PIBID Project and its textures: reflections on teacher education, Special Education and Mathematics}

\begin{abstract}
This text aims to analyze the constitution of a training process based on the teaching experience, focusing on the space for articulation between a special education teacher and teachers in mathematics in the development of a proposal linked to the Institutional Initiation Scholarship Program

\footnotetext{
${ }^{1}$ Doutora em Educação pelo Programa de Pós-Graduação em Educação da Universidade Federal do Rio Grande do Sul (UFRGS), Professora de Educação Especial no Colégio de Aplicação (UFRGS). E-mail: mayacsilva@gmail.com ORCID iD: https://orcid.org/0000-0001-8716-0768

${ }^{2}$ Graduando do Curso de Licenciatura em Matemática da Universidade Federal do Rio Grande do Sul (UFRGS). E-mail: thayllesleal@gmail.com ORCID iD: https://orcid.org/0000-0002-9229-7635

3 Doutor em Informática na Educação pelo Programa de Pós-Graduação Informática em Educação da Universidade Federal do Rio Grande do Sul (UFRGS). Professor Adjunto do Departamento de Matemática Pura e Aplicada do Instituto de Matemática e Estatística (IME) da UFRGS, com atuação em disciplinas do DMPA. É professor/orientador credenciado ao Pós-Graduação em Ensino de Matemática (UFRGS). E-mail: sychocki.rodrigo@gmail.com ORCID iD: http://orcid.org/0000-0002-7406-2517
} 


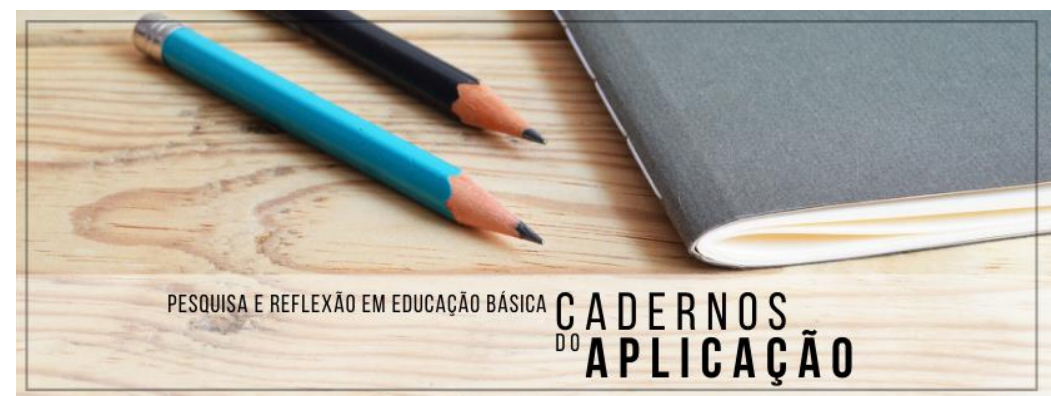

Cadernos do Aplicação

https://seer.ufrgs.br/CadernosdoAplicacao

Publicação Ahead of Print

ISSN 2595-4377 (online)

Porto Alegre | jul-dez. 2021 | v.34 | n.2

to Teaching (PIBID). The proposal was based on the pedagogical action of a scholarship holder of the program in question, graduating from the Licentiate Degree in Mathematics at the Specialized Educational Service. Therefore, based on a qualitative approach methodology, there was a literature review on the subject and an analysis of the experience in question, from the observation and documental analysis of reports and records built along the way. Data were read and interpreted from the theoretical framework related to systemic thinking, as well as in the light of the ideas of scholars in the field of teacher education. From this, it is possible to state that the teacher education resulting from the experience analyzed in the project was constituted, as a priority, from the articulation between the teachers involved, through a network work, with space for dialogue, planning in set and exchanges of experiences involved in the pedagogical process.

Keywords: Teacher education. Special education. Math. School inclusion.

\title{
Proyecto PIBID y sus tesituras: reflexiones sobre formación docente, Educación Especial y Matemáticas
}

\begin{abstract}
Resumen: Este texto tiene como objetivo analizar la constitución de un proceso de formación basado en la experiencia docente, enfocándose en el espacio de articulación entre un docente de Educación Especial y docentes de Matemáticas en el desarrollo de una propuesta vinculada al Programa Institucional de Becas de Iniciación a la Docencia (PIBID). La propuesta se basó en la acción pedagógica de un becario del programa en cuestión, egresado de la Licenciatura en Matemáticas en el Servicio de Educación Especializada. Por lo tanto, con base en una metodología de enfoque cualitativo, se realizó una revisión de la literatura sobre el tema y un análisis de la experiencia en cuestión, a partir de la observación y análisis documental de informes y registros. Los datos fueron leídos e interpretados desde el marco teórico relacionado con el pensamiento sistémico, así como a la luz de las ideas de académicos en el campo de la formación docente. A partir de esto, es posible afirmar que la formación docente resultante de la experiencia analizada en el proyecto se constituyó, como prioridad, a partir de la articulación entre los docentes involucrados, a través de un trabajo en red, con espacios de diálogo, planificación en conjunto e intercambios. de experiencias involucradas en el proceso pedagógico.
\end{abstract}

Palabras clave: Educación del profesorado. Educación especial. Matemáticas. Inclusión escolar.

\section{Introdução}

Os últimos vinte anos representam inúmeros avanços no que concerne à escolarização de alunos público-alvo da educação especial em uma perspectiva inclusiva. Podemos afirmar, de forma mais específica, que as iniciativas e movimentos políticos que ocorreram a partir dos anos 2000 foram fundamentais na construção dessa perspectiva e na democratização do acesso ao ensino regular pelas pessoas com deficiência. 


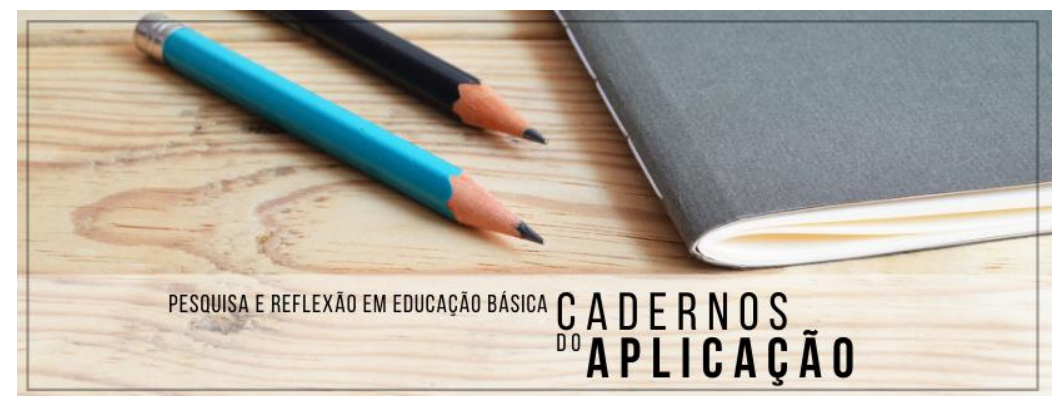

Cadernos do Aplicação

https://seer.ufrgs.br/CadernosdoAplicacao

Publicação Ahead of Print

ISSN 2595-4377 (online)

Porto Alegre | jul-dez. 2021 | v.34 | n.2

No ano de 2008, implementou-se a Política Nacional de Educação Especial na perspectiva da educação inclusiva (BRASIL, 2008). Esse documento, além de representar uma alteração na perspectiva política para a área ao afirmar que os sujeitos público-alvo da Educação Especial devem frequentar o ensino regular e receber atendimento educacional especializado de forma complementar ou suplementar à escolarização em classes comuns, apresenta outras mudanças importantes. O público-alvo da Educação Especial, a partir dessa política, passa a ser representado por três diferentes grupos: pessoas com deficiência; pessoas com transtornos globais do desenvolvimento; e pessoas com altas habilidades/superdotação ${ }^{4}$.

O objetivo da Política Nacional de Educação Especial envolve:

[...] assegurar a inclusão escolar de alunos com deficiência, transtornos globais do desenvolvimento e altas habilidades/superdotação, orientando os sistemas de ensino para garantir: acesso ao ensino regular, com participação, aprendizagem e continuidade nos níveis mais elevados do ensino; transversalidade da modalidade de educação especial desde a educação infantil até a educação superior; oferta do atendimento educacional especializado; formação de professores para o atendimento educacional especializado e demais profissionais da educação para a inclusão; participação da família e da comunidade; acessibilidade arquitetônica, nos transportes, nos mobiliários, nas comunicações e informação; e articulação intersetorial na implementação das políticas públicas (BRASIL, 2008, p. 14).

Torna-se fundamental ressaltar que a Política Nacional de Educação Especial, na perspectiva da educação inclusiva, apresenta ainda um conceito de Educação Especial transversal a todas as etapas, níveis e modalidades de ensino. A partir da publicação deste documento, passa-se a observar - como um dos efeitos a serem apontados - mudanças significativas nas matrículas dos alunos público-alvo da educação especial, as quais passam a apresentar um crescimento na escola regular e, no mesmo sentido, um decréscimo nas escolas especiais. Segundo Baptista (2019):

\footnotetext{
${ }^{4}$ De forma geral, como o grupo de pessoas com deficiência representa o maior número de sujeitos da Educação Especial, utilizaremos o conceito de "pessoas com deficiência" ou "público-alvo da educação especial", referindonos a todo o público.
} 


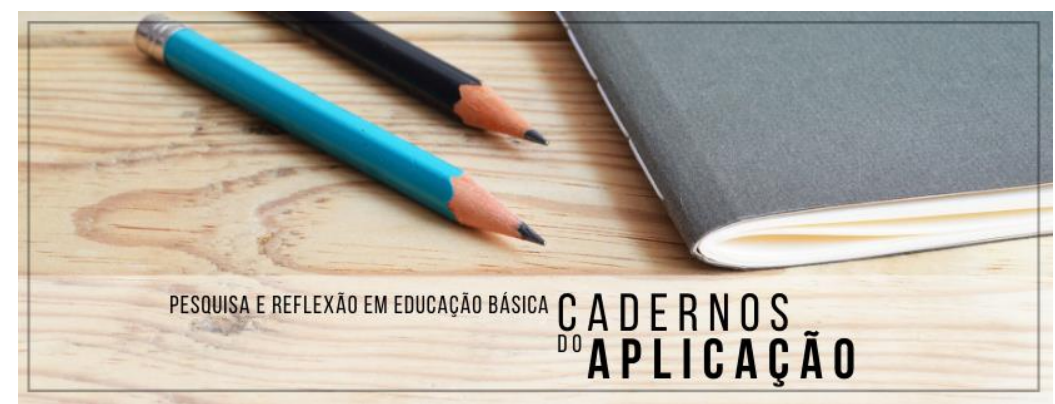

Cadernos do Aplicação

https://seer.ufrgs.br/CadernosdoAplicacao

Publicação Ahead of Print

ISSN 2595-4377 (online)

Porto Alegre | jul-dez. 2021 | v.34 | n.2

As significativas alterações dos índices educacionais relativos à escolarização das pessoas com deficiência devem ser analisadas a partir de uma mudança de gestão, iniciada com o primeiro governo do Presidente Lula da Silva, em 2003. A meta de inclusão escolar passa a integrar um plano de ação que tendia a buscar que os direitos sociais ganhassem efetividade, envolvendo diferentes grupos que têm um histórico de desvantagem, como ocorre com as pessoas com deficiência (BAPTISTA, 2019, p. 11).

Portanto, faz-se necessário perceber que essas mudanças se relacionam ao contexto histórico em questão, no qual houve destaque e investimento em políticas sociais. Assim, dado o aumento do número de matrículas desses estudantes no ensino regular e o discurso de despreparo docente, que ainda aparece de forma intensa quando nos remetemos aos processos inclusivos, torna-se emergente uma discussão que se relaciona à formação docente (SILVA, 2011; TAVARES; SANTOS; FREITAS, 2016; LIMA; JERÔNIMO; GOUVEIA, 2020).

A Lei no 13.146, de 6 de julho de 2015, mais conhecida como Lei Brasileira de Inclusão, em seu capítulo IV, que se relaciona ao direito à educação, enfatiza que é dever do estado "assegurar, criar, desenvolver, implementar, incentivar, acompanhar e avaliar [...] a adoção de práticas pedagógicas inclusivas pelos programas de formação inicial e continuada de professores e oferta de formação continuada para o atendimento educacional especializado". (BRASIL, 2015). Nesse sentido, compreendemos a importância de discutir, cada vez mais, os processos formativos que estão relacionados com essa temática.

A proposição do presente estudo envolve uma análise e reflexão acerca de espaços de formação que decorrem da prática pedagógica, articulando a experiência derivada da ação do professor na perspectiva inclusiva. Para tanto, o objetivo do estudo envolve desenvolver uma análise acerca da constituição de um processo formativo pautado na experiência docente, com foco no espaço de articulação entre duas áreas - Educação Especial e Matemática - no desenvolvimento de uma proposta vinculada ao programa Programa Institucional de Bolsas de Iniciação à Docência (PIBID). A análise se constituirá a partir de uma abordagem qualitativa, com foco na análise documental e na observação. 


\section{Articulações entre Educação Especial e Matemática na formação de professores}

O PIBID promove uma articulação entre universidades e escolas de educação básica a partir do objetivo de, segundo o Portal do Ministério da Educação (MEC), antecipar o vínculo entre futuros professores e salas de aulas de escolas públicas. Tal iniciativa aproxima espaços que historicamente são percebidos como distantes e que colocam a universidade como um lugar de constituição de teorias e a escola como um espaço de práticas.

Compreendemos que essa concepção pode ser considerada simplista e redutora, já que não há possibilidade de considerarmos a separação entre os pilares da teoria e da prática. Ambas estão correlacionadas e aproximar os espaços da universidade e das escolas de educação básica torna-se fundamental para que compreendamos a articulação entre esses dois pilares. Com isso, convergimos ao que expõe Tardif (2013) ao afirmar que "a relação entre a pesquisa universitária e o trabalho docente nunca é uma relação entre uma teoria e uma prática, mas uma relação entre atores, entre sujeitos cujas práticas são portadoras de saberes.” (TARDIF, 2013, p. 237).

Logo, optamos por realizar uma busca por estudos que apresentam experiências que articulam as áreas da Educação Especial e da Matemática. Com base em um levantamento no Portal de Periódicos da Coordenação de Aperfeiçoamento de Pessoal de Nível Superior (CAPES), entre 2010 e 2020, encontramos nove trabalhos; na busca, consideramos trabalhos cujo assunto contivesse os termos "Educação Especial" e "Matemática" de forma relacionada e, assim, reagrupamos os resultados apenas com textos em português. Nessa primeira busca, encontramos um maior número de trabalhos sobre essa questão, os quais abordam a falta de disciplinas em cursos de formação e/ou a ausência de abordagem de tópicos associados à temática nos cursos já existentes. Petró (2014) afirma que a causa disso é a falta de articulação do professor de Matemática e do professor do atendimento educacional especializado, o que tem efeitos no processo de inclusão do aluno, pois o trabalho dos profissionais acaba acontecendo de maneira fragmentada e isolada. Ainda assim, em alguns dos trabalhos em questão, nos quais foram apresentados planejamentos envolvendo as duas áreas, podem ser percebidos resultados satisfatórios, pois as atividades demonstraram um ganho significativo para os alunos em estudo. Tais apontamentos nos oferecem indícios acerca da importância do 
trabalho articulado entre as diferentes áreas de ensino (aqui representada pela Matemática) e a Educação Especial no processo de escolarização de estudantes com deficiência.

Em um momento posterior da pesquisa, buscamos por trabalhos cujo assunto contivesse as palavras "Educação Especial" e "PIBID" ou "formação docente" de forma relacionada. Encontramos treze trabalhos, os quais apresentam diversos processos de formação docente, entre os quais, podemos destacar as formações continuadas oferecidas pelas secretarias de educação e as aprendizagens constituídas a partir da formação inicial proporcionada pelo PIBID. Rosseto (2015) afirma, em seu estudo, sobre a necessidade de mais professores na área da Educação Especial, mas conclui que a formação continuada de maneira remota (EAD) causa uma desvalorização da Educação Especial enquanto campo de conhecimento, salientando a importância da prática docente para a formação na área. Corroborando para isso, Honnef e Costas (2012, p. 121) afirmam que a "formação para a educação especial na perspectiva inclusiva pode acontecer nas escolas através do trabalho em parceria entre professores da classe comum e o professor de Educação Especial, através da constituição de um espaço consistente de diálogo entre os docentes".

Torna-se possível observar que são poucas as produções que articulam as áreas da Educação Especial e da Matemática, o que pode ser entendido como um dos efeitos relacionados à não obrigatoriedade de uma disciplina acerca da temática no currículo das licenciaturas. Cabe destacar que a legislação vigente direciona para uma necessidade de trabalho no âmbito das licenciaturas com conteúdo e temáticas que se relacionam à Educação Especial, mas não estabelece uma obrigatoriedade de disciplinas específicas. A única disciplina de caráter obrigatório é a Língua Brasileira de Sinais (Libras), estabelecida por meio de exigência prevista no Decreto ${ }^{\circ} 5.626$, de 22 de dezembro de 2005, o qual não contempla todas as temáticas que se articulam à Educação Especial e à inclusão escolar, corroborando com o discurso de professores que afirmam não estar preparados para o trabalho junto aos estudantes público-alvo.

Os textos apresentados envolvem, ainda, diversas ações diante da reconfiguração do trabalho docente e que envolvem a Educação Especial. Foram encontrados e mencionados neste artigo textos que apresentam e refletem uma diversidade de ações, sejam essas sobre a formação do professor, para que se possa trabalhar junto com os estudantes, sejam sobre o 


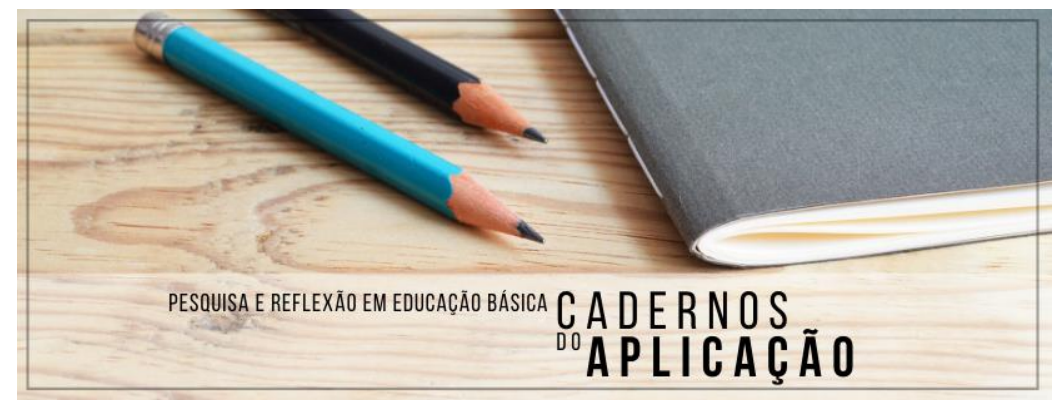

Cadernos do Aplicação https://seer.ufrgs.br/CadernosdoAplicacao

Publicação Ahead of Print

ISSN 2595-4377 (online)

Porto Alegre | jul-dez. 2021 | v.34 | n.2

desenvolvimento/construção de materiais para o ensino da Matemática. No entanto, a partir de um olhar sobre os estudos consultados, reiteramos uma necessidade de reflexão sobre a inclusão, em caráter obrigatório, nos currículos das licenciaturas, com o estudo de políticas públicas, a introdução de práticas pedagógicas e a produção de materiais didáticos que envolvam a educação inclusiva.

\section{Formação de professores a partir da reflexão sobre a experiência no PIBID: articulações teóricas}

Torna-se importante destacar que a concepção de formação discutida no âmbito do presente estudo pauta-se na perspectiva da complexidade, associada ao pensamento sistêmico. A partir dessa compreensão:

O pressuposto da complexidade orienta a desconstituição da visão do mundo como algo pré-estabelecido e a percepção da necessidade de contextualização dos fenômenos. A partir dessa compreensão, passamos a perceber a ideia de um sistema constituído por um todo correlacionado, percebendo a impossibilidade de análise das partes de um sistema separadamente ou sem relacioná-lo ao contexto em que está inserido (SILVA, 2015, p. 63-64).

Portanto, a análise aqui proposta pautar-se-á em uma compreensão de um todo relacionado, buscando analisar a constituição de uma rede que se formou entre universidade e escola e entre os sujeitos que compuseram o processo formativo alavancado pelo projeto. No mesmo sentido, percebemos a formação docente a partir do conceito de instabilidade, como um processo contínuo, ou seja, não existe um momento específico em que findaria, dada a dinamicidade da vida. A formação, a partir dessa perspectiva, envolve um constante processo de tornar-se, de vir a ser professor.

Da mesma forma, relacionados aos conceitos de complexidade e instabilidade, os quais estão imbricados no pensamento sistêmico, compreendemos a importância do conceito de intersubjetividade, o qual está relacionado à ideia de que tudo o que é observado é visto a partir do observador, ou seja, não existe neutralidade em um processo de observação. Assim, todos os sujeitos envolvidos no processo observam "uma realidade", e não "a realidade", tendo em vista a subjetividade de tal composição. Logo, a construção do processo formativo tem efeitos 
diversos sobre os sujeitos que o constituem, tendo em vista que aquilo que faz sentido para cada um instaura-se à sua própria estrutura e à sua própria experiência.

De acordo com Silva (2015), que trabalha a partir do conceito de autopoiese (MATURANA; VARELA, 2001) para discutir o conceito de formação a partir da experiência, podemos afirmar que essa formação envolve a estrutura singular de cada sujeito, mas que ela decorre das relações que se constituem com o meio e com os demais sujeitos que constituem uma rede. Aliamo-nos a essa compreensão ao afirmarmos o conceito de formação pela experiência como "uma formação de si nunca solitária, sempre em relação, a partir de experiências compartilhadas, trocadas, vividas a partir da interação" (SILVA, 2015, p.18).

No sentido de pensar uma formação que se constitui a partir da experiência, embasamonos nas discussões apresentadas por Maurice Tardif e Francisco Imbernón. De acordo com Tardif (2013), o trabalho docente se constitui a partir de diferentes saberes, entre eles, os experienciais, aqueles que se constituem na prática, na ação docente do professor. Na mesma medida, o autor afirma a impossibilidade de pensarmos a prática desvinculada da teoria, ou seja, toda prática envolve uma teoria e vice-versa. Portanto, torna-se importante destacarmos que, ao falarmos de uma formação derivada da experiência, não significa que a mesma seja esvaziada de teoria.

Imbernón (2012) coloca em voga a percepção da importância da constituição de processos investigativos elaborados junto com os professores, tendo em vista que esse processo de construção conjunta se organiza a partir do diálogo, da troca, do compartilhamento de ideias, da discussão que envolve um planejamento e os efeitos deste.

A perspectiva da formação a partir da experiência, conforme afirmamos anteriormente, deve considerar as relações traçadas na rede em que o professor está inserido, a qual envolve o meio (neste caso, a universidade e a escola) e os sujeitos envolvidos, que, no âmbito do presente estudo, são o grupo de professores e os alunos participantes. Dessa forma, o diálogo como eixo centralizador deve ser considerado elemento fundamental para a construção da perspectiva de formação que se constituiu a partir do projeto.

O projeto PIBID busca, na sua essência, promover a experiência de sala de aula por meio da fusão entre teoria e prática. Esse primeiro contato com a escola tem sua importância, 


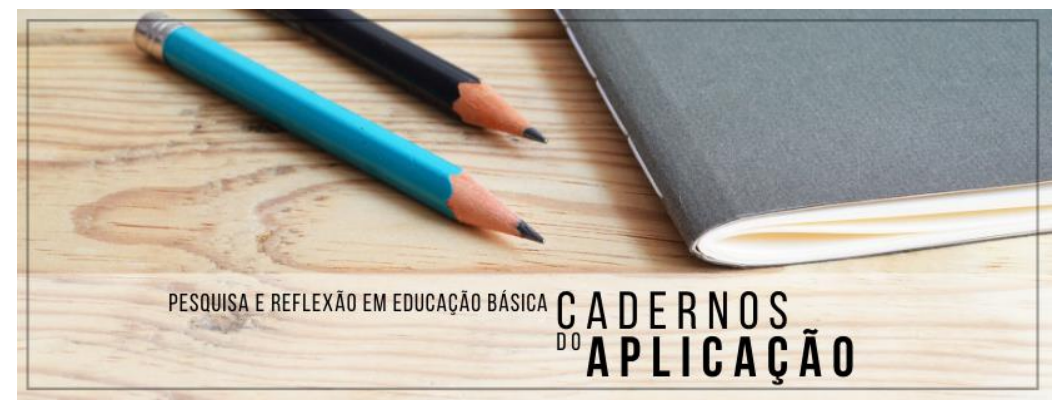

Cadernos do Aplicação

https://seer.ufrgs.br/CadernosdoAplicacao

Publicação Ahead of Print

ISSN 2595-4377 (online)

Porto Alegre | jul-dez. 2021 | v.34 | n.2

pois, como afirmam Cavalcante et al. (2019), o estudante da licenciatura retorna à escola como futuro profissional.

Nesse sentido, a participação no PIBID tem proporcionado uma experiência prenhe de aprendizagens, tanto para os licenciandos quanto para os professores experientes da escola e universidade. Essa aproximação do futuro contexto de trabalho é uma experiência singular e significativa, pois apesar deste ser um ambiente familiar a todos os candidatos à docência, uma vez que vivenciaram a realidade da escola quando eram alunos, voltar-se para esta instituição na condição de estudante de licenciatura, de quem estuda e busca tornar-se um profissional da área, contribui para que este um ambiente seja novo e as situações que antes passavam despercebidas, agora são motivo para novas reflexões. (p. 6).

Além disso, o projeto PIBID tem um caráter inovador, no qual o bolsista pode criar, promover e vivenciar metodologias diferenciadas, proporcionando, assim, uma vivência de momentos distintos àqueles experienciados quando aluno e fazendo um momento do (re)pensar o fazer da ação profisssional que está exercendo. Ao se tornar um protagonista na ação docente, o bolsista tem a oportunidade de instigar e desafiar o estudante para novas percepções, distintas das quais ele já está inserido e habituado. Essa experiência deve formar o professor, que começa a compreender a necessidade do saber para o estudante e suas finalidades, como ressalvam Paniago, Sarmento e Rocha (2018):

Diante disso, ao analisar a aprendizagem dos futuros professores, colocamos em evidência as várias dimensões dos saberes da docência, destacando, como fundamental ao professor, a capacidade de mobilizar e decidir qual deve ser o saber a ser utilizado nas diversas e singulares situações do trabalho docente. (p. 6).

Paniago e Sarmento (2017) sinalizam as contribuições do programa para a investigação na formação para além da sala de aula:

O PIBID apresenta um espaço rico e prenhe em possibilidades para a aprendizagem da docência e formação na e para a pesquisa, para o que concorrem vários intervenientes: os licenciandos podem, por meio da investigação, adentrar os diversos espaços da escola de Educação Básica, ocupar as bibliotecas, ter contato com as Tecnologias da Informação e Comunicação (TICs); podem vivenciar as relações multifacetadas, heterogêneas, afetivas, complexas de sala de aula e contorno sociocultural da comunidade educativa e, por fim, podem realizar projetos de ensino e de intervenção com possibilidades de se transformarem em projetos de pesquisa (PANIAGO, SARMENTO, 2017, p. 784). 


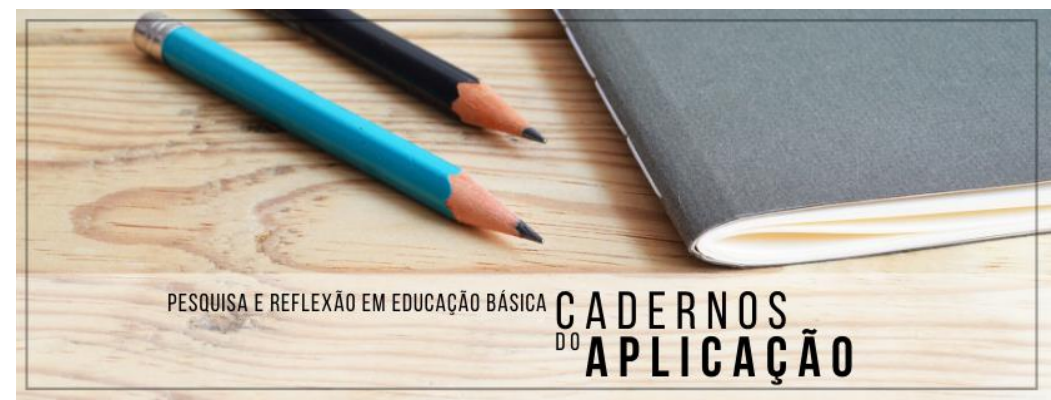

Cadernos do Aplicação https://seer.ufrgs.br/CadernosdoAplicacao

Publicação Ahead of Print

ISSN 2595-4377 (online)

Porto Alegre | jul-dez. 2021 | v.34 | n.2

Desse modo, Paniago e Sarmento (2017) indicam que o PIBID é um espaço oportuno para a construção dessa aprendizagem docente. Compreendemos que os referenciais teóricos discutidos se relacionam ao espaço de articulação que se organizou, pois a prática docente em nossa proposta foi realizada a partir do eixo norteador do diálogo. Logo, as relações foram concebidas como prioritárias na condução dos processos formativos analisados, sendo, ainda, fundamentais para a condução do trabalho pedagógico proposto.

Por isso, os elementos apresentados nesta seção tornam-se instrumentos para pensar e refletir sobre a prática e, consequentemente, sobre a formação docente. Na próxima seção, são explicadas as características metodológicas utilizadas, bem como as características do projeto PIBID em questão.

\section{Organização metodológica das ações: materiais e métodos}

A investigação aqui proposta, conforme mencionado anteriormente, ancora-se em uma abordagem qualitativa, de forma que destacamos a importância do processo em detrimento de um resultado ou produto. Como instrumentos metodológicos prioritários, optamos pela análise documental que envolveu o caderno de campo mantido pelo bolsista do PIBID e os relatórios elaborados por ele, bem como, pelo processo de observação. Compreendemos, ancorados no referencial teórico que se associa ao pensamento sistêmico, que o processo de observação envolveu, além do bolsista, a professora de Educação Especial, que sempre esteve presente durante o desenvolvimento das atividades e nas intervenções.

Para além disso, compreendemos que o processo de análise implica todos os elementos que constituem a rede formativa e o processo de planejamento, execução e avaliação das proposições, os quais: o professor do curso de Matemática da Universidade, o bolsista licenciando do curso de Matemática e a professora de Educação Especial da escola de educação básica.

Torna-se importante mencionar que o processo de observação envolveu a participação ativa dos pesquisadores presentes no desenvolvimento das atividades, o que seria chamado de “observação participante". Porém, com base no referencial teórico utilizado na investigação, afirmamos a compreensão da impossibilidade de não participação no campo, mesmo que não 


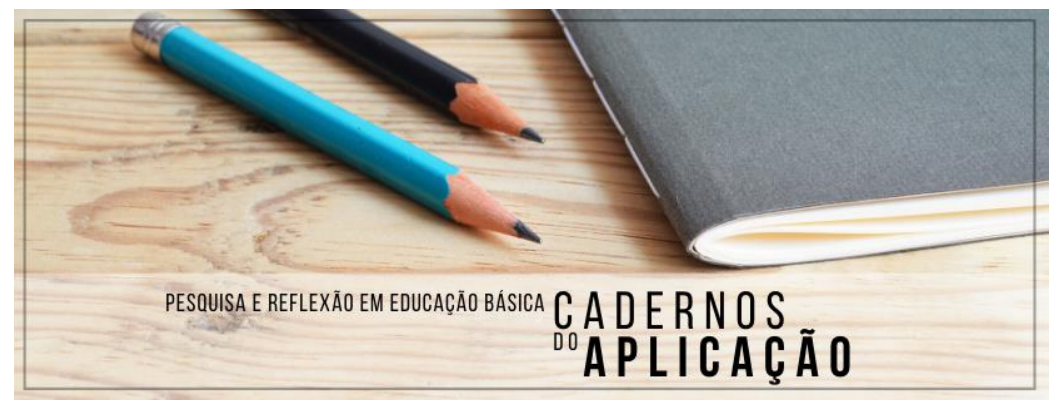

Cadernos do Aplicação

https://seer.ufrgs.br/CadernosdoAplicacao

Publicação Ahead of Print

ISSN 2595-4377 (online)

Porto Alegre | jul-dez. 2021 | v.34 | n.2

houvesse intervenção daquele que observa, tendo em vista que sua presença já tem efeitos no contexto observado. Segundo Silva (2015), apoiada no pensamento sistêmico:

Tudo aquilo que é observado por alguém, portanto, é também descrito em relação às suas experiências. Reafirmo assim a percepção de que não existe uma única descrição, ou, uma única verdade. Existem inúmeras descrições possíveis, bem como inúmeras verdades, uma vez que são construídas por alguém que não pode desvincular-se de suas bagagens anteriores para observar e descrever (SILVA, 2015, p. 86).

Compreendemos, dessa forma, que o observador está sempre implicado naquilo que observa, sendo, portanto, a observação, necessariamente, também participação, pois produz efeitos sobre o objeto do conhecimento (MATURANA; VARELA, 2001).

Assim, a proposta que analisamos no âmbito do presente texto nasce a partir da organização do coordenador do PIBID Matemática da Universidade e da supervisora do colégio, os quais objetivavam encaminhar os bolsistas para determinados anos de ensino no intuito de começar o acompanhamento letivo. Por solicitação do bolsista, que já possuía interesse na área da Educação Especial, mas não possuía experiência, a professora/educadora especial da escola foi consultada para o desenvolvimento de um possível trabalho articulado.

Os estudantes atendidos pelo bolsista em articulação com a professora de Educação Especial eram dois alunos do ensino médio, dos quais um frequentava o segundo ano e o outro, o terceiro ano. $\mathrm{O}$ atendimento educacional especializado ocorria à tarde, no contraturno da escolarização, conforme indica a legislação para a área da Educação Especial. Ambos eram atendidos uma vez por semana, com uma carga horária que envolvia dois períodos de 45 minutos cada, e em dupla.

A organização das ações em sala de aula era feita de maneira triangular, sendo primeiramente enviado o plano de aula para o coordenador do projeto PIBID Matemática e, logo após as alterações solicitadas, as atividades eram encaminhadas para a professora de Educação Especial, para que, assim, também houvesse uma avaliação sobre a exequibilidade das ações. Nesse sentido o planejamento era construído a partir das necessidades/demandas observadas nos estudantes que frequentavam o atendimento especial especializado e as ideias eram debatidas com a professora de Educação Especial. Depois, era desenhada a arquitetura do plano de aula. Esse movimento demonstra a organização de uma dinâmica viva, orgânica e 


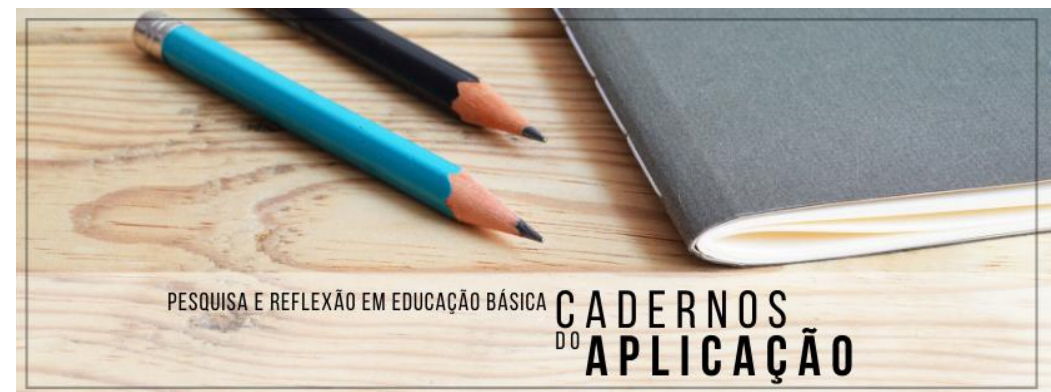

Cadernos do Aplicação https://seer.ufrgs.br/CadernosdoAplicacao

Publicação Ahead of Print

ISSN 2595-4377 (online)

Porto Alegre | jul-dez. 2021 | v.34 | n.2

pautada necessariamente no diálogo e no compartilhamento, com idas e vindas de um plano de aula dialogado.

A análise apresentada no texto será desenvolvida com base no caderno de campo e dos relatórios desenvolvidos pelo bolsista do PIBID apoiado por leituras sucessivas e pelo levantamento daquilo que compreendemos como emergente a partir do objetivo elencado. A escrita dos relatórios da aula com auxílio do caderno de campo contou com a colaboração das falas, das resoluções e dos gestos dos estudantes durante a prática, ou seja, as informações foram construídas a partir do processo de observação do bolsista do projeto. Entendeu-se, portanto, que a construção desses documentos possibilitou ao bolsista produzir reflexões sobre a sua própria prática pedagógica.

Além disso, serão levadas em consideração nossas próprias experiências e participações no projeto, evocando, dessa forma, em movimento de associação às leituras, um processo de observação. Compreendemos que o caderno de campo, assim como os relatórios, é composto a partir daquilo que Bogdan e Biklen (1994) irão chamar de notas de campo. Segundo os autores, após retornar do espaço investigado, é comum que o investigador registre o que ocorreu, assim:

[...] ele ou ela dão uma descrição das pessoas, objetos, lugares, acontecimentos, atividades ou conversas. Em adição e como parte dessas notas, o investigador registrará ideias, estratégias, reflexões e palpites, bem como, os padrões que emergem. Isto são as notas de campo: o relato escrito daquilo que o investigador ouve, vê, experiencia e pensa [...] (p. 150).

A análise ancorou-se em uma abordagem qualitativa, com atenção prioritária ao processo formativo que se instituiu. Nesse sentido, podemos considerar que o movimento que envolveu o projeto articulou-se a partir do pressuposto prioritário do diálogo como orientador das práticas. Reafirmamos que todo o planejamento a ser desenvolvido no âmbito do atendimento educacional especializado era dialogado entre os três professores (o orientador do projeto PIBID Matemática, o bolsista de licenciatura em Matemática e a professora da escola de Educação Especial) e que essa arquitetura de ações assume uma importância fundamental na compreensão de formação aqui discutida. 


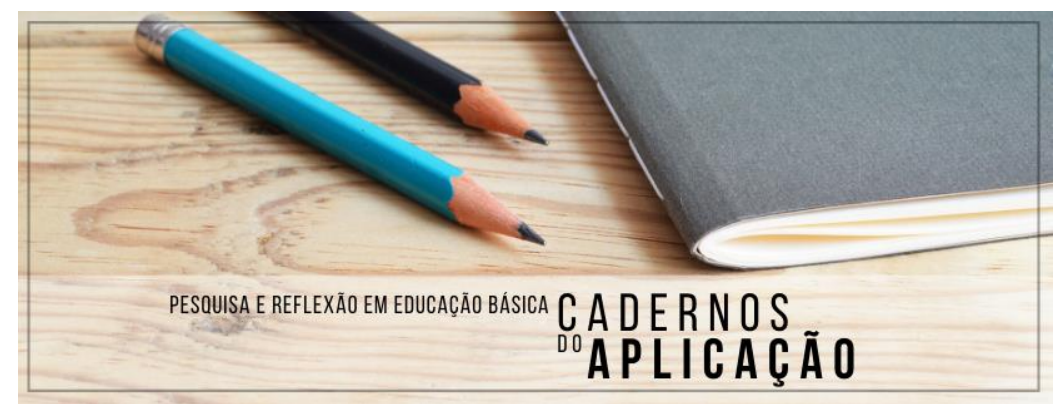

Cadernos do Aplicação

https://seer.ufrgs.br/CadernosdoAplicacao

Publicação Ahead of Print

ISSN 2595-4377 (online)

Porto Alegre | jul-dez. 2021 | v.34 | n.2

Para os planejamentos das aulas, foram elaborados jogos e atividades voltadas para o ensino de Matemática, a fim de proporcionar uma aprendizagem lúdica e pautada prioritariamente no uso de materiais concretos. Segundo Rosa, Silva e Silva:

Os jogos foram preparados/organizados pelo bolsista com materiais de fácil acesso, em sua maioria construídos com papel, tesoura, papelão e canetas coloridas. Ao todo foram preparados/organizados onze materiais, que foram subdivididos em três eixos (Estatística, Trigonometria e Geometria). Além desses materiais preparados pelo bolsista, utilizou-se, também, os do laboratório de ensino do colégio (ROSA, SILVA e SILVA, 2020, p. 7).

No artigo, Rosa, Silva e Silva (2020) exploram quais foram especificamente os materiais construídos e, a partir de seu uso, quais eram e como os objetivos previamente elaborados foram sendo alcançados ao longo das ações que envolveram a prática pedagógica.

\section{Uma análise da formação no âmbito do projeto PIBID: tessituras entre a} Educação Especial e a Matemática

O planejamento das propostas envolvendo o atendimento educacional especializado tinha a intenção de propor atividades lúdicas e convidativas, como jogos e materiais pedagógicos concretos. Tais atividades também visavam potencializar as habilidades dos estudantes que eram atendidos e, a partir disso, traçar um perfil que considerasse seus conhecimentos prévios e dificuldades, o que colaborou para o planejamento. Esse material era supervisionado pelo orientador da Matemática, no intuito de transigir se o conteúdo didático era apropriado para a proposta didática da escola, e pela professora da Educação Especial, que verificava se as atividades tinham articulação com as necessidades observadas nos estudantes, bem como relação com o trabalho proposto no atendimento educacional especializado.

As orientações não se limitavam apenas aos momentos específicos de planejamento, mas também a partir de diálogos que ocorriam por meio de conversas e $e$-mails. Tais trocas possibilitaram um desenvolvimento didático e um movimento formativo, pois enriqueciam o planejamento e as ideias para a condução das próximas aulas, bem como fomentavam as experiências, práticas e diálogos entre a Matemática e a Educação Especial. Para além disso, 
indica uma organização que se constitui tomando as relações como princípio basilar, pautandose, desta forma, no paradigma da complexidade (VASCONCELLOS, 2012).

Durante o percurso analisado, foram produzidas dezessete atividades. Para cada uma das atividades, as quais nem sempre se constituíam em uma única aula, foi produzido e publicado, no site do projeto, um relatório de cunho reflexivo, que buscava explanar de que forma os objetivos construídos no planejamento eram, de alguma forma, alcançados a partir da prática pedagógica. Os cadernos de campo também foram utilizados na produção dos relatórios, já que nesses documentos, além de uma descrição de como as aulas ocorriam no espaço do atendimento educacional especializado, eram retomados quais tinham sido os percursos percorridos pelos estudantes participantes no desenvolvimento e estudo dos conteúdos, em suas construções (facilidades e dificuldades) e nas demais ações que ocorreram no exercício da prática pedagógica.

Tanto nos cadernos de campo quanto nos relatórios tornou-se possível observar com mais detalhes como o trabalho entre a Matemática e o atendimento educacional especializado estava sendo articulado, buscando trabalhar com base nas questões observadas nos estudantes, de modo que as especificidades relacionadas ao processo de aprendizagem de cada um deles fossem respeitadas. Tal movimento envolve o trabalho do professor de atendimento educacional especializado que deve, conforme indicações dos documentos normativos (BRASIL, 2009), articular-se aos professores de sala de aula regular, no sentido de qualificar o processo de ensino e aprendizagem do aluno público-alvo da educação especial, garantindo sua participação nas atividades.

Nesses cadernos de campo eram registrados falas, conversas e gestos, anotações acerca dos estudantes para a construção posterior dos relatórios. Já nos relatórios eram descritos todos os acontecimentos vividos na aula e reflexões a partir desses momentos, bem como a didática usada e o assunto abordado no encontro. Os espaços de escrita propostos por meio destes instrumentos podem ser vistos como formativos, na medida em que o bolsista do PIBID Matemática estabelecia algumas reflexões acerca de suas práticas, conforme trechos destacados ${ }^{5}$ do relatório referentes ao primeiro encontro:

\footnotetext{
${ }^{5}$ Optamos por apresentar no artigo os trechos dos relatórios em quadros de maneira a diferenciá-los das citações diretas utilizadas ao longo do texto.
} 


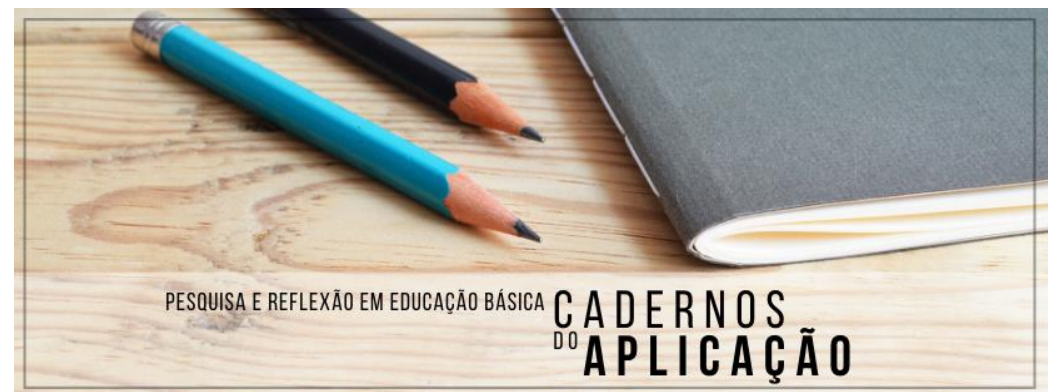

Cadernos do Aplicação

https://seer.ufrgs.br/CadernosdoAplicacao

Publicação Ahead of Print

ISSN 2595-4377 (online)

Porto Alegre | jul-dez. 2021 | v.34 | n.2

\section{Quadro 1 - Trecho do relatório 1}

Ao todo, as atividades demoraram mais tempo que o previsto, logo, para a atividade com o teodolito, foi mais curta que o previsto. O aluno escolheu um ponto para medir. Ele escolheu uma lâmpada da sala. Assim, fazendo o uso de uma fita métrica para medir a distância do chão entre o teodolito e a lâmpada e o ângulo formado pelo teodolito, descobrimos a altura do chão até a altura através da tangente [...] Os alunos aparentaram ficar muito entusiasmados com a última atividade, pois foi algo que nunca tiveram o contato na sala de aula regular. O que motivou-me trazer cada vez mais de atividades diferentes das praticadas na sala de aula [...].

Fonte: Arquivo pessoal.

O mesmo movimento pode ser percebido na descrição realizada no âmbito do segundo encontro: "essa aula foi muito importante para mim, devido a tomada de decisões que tive que fazer e, mesmo com um plano, a maneira que tive que realizá-lo [...]" (trecho do relatório 2). Essa decisão foi tomada a partir de uma observação, no momento da aula, sobre se seria possível continuar explicando os conceitos da atividade ou se seria melhor abordá-los em um outro momento, com mais recursos. Assim, a decisão tomada foi elencar esses conceitos para um momento posterior, com mais recursos. Além disso, o que ocorria em cada um dos encontros era utilizado como pista para a constituição de um próximo planejamento, como afirma ao final da descrição de uma atividade: "reparei que precisaria de mais tempo e uma atividade lúdica para que a ideia de área de tais figuras fosse estabelecida" (trecho do relatório 11). Tais elementos indicam que o planejamento e a proposição de atividades ocorriam de forma dinâmica, partindo das pistas que eram ofertadas pelos estudantes em cada um dos atendimentos. Tal organização encontra sintonia no pensamento sistêmico, na medida em que se organiza a ação docente com base no pressuposto da complexidade (VASCONCELLOS, 2012), compreendendo que os processos de conhecer não se constituem de forma linear, mas sim a partir do movimento.

Para além de uma retomada constante acerca de aspectos relacionados à sua ação docente, o bolsista do projeto PIBID Matemática utilizou o espaço do relatório para elencar as habilidades e dificuldades percebidas nos estudantes, aproveitando o espaço para refletir acerca das dinâmicas que se instituíam na escolarização dos mesmos: "pude observar que o aluno apresentou domínio, facilidade e interesse na atividade, na qual comecei a questionar-me se o aluno poderia apresentar nervosismo apenas na prova" (trecho do relatório 6); "o mesmo apresentava de uma imaginação e criativa (sic) muito admirável, me chamando a atenção e 


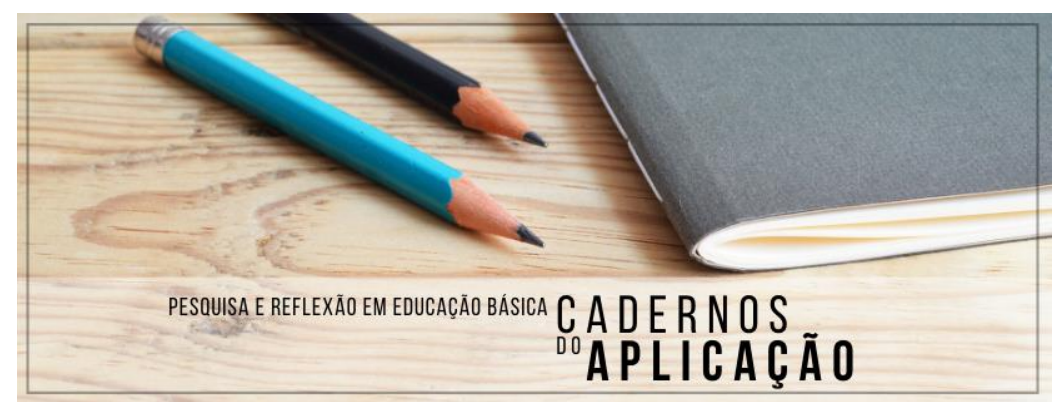

Cadernos do Aplicação

https://seer.ufrgs.br/CadernosdoAplicacao

Publicação Ahead of Print

ISSN 2595-4377 (online)

Porto Alegre | jul-dez. 2021 | v.34 | n.2

questionando sobre as palavras que uso para designar uma atividade [...]" (trecho do relatório 17).

Além desses aspectos, percebe-se a tendência de o bolsista buscar articular as estratégias propostas com aspectos do cotidiano, compreendendo a importância de os alunos construírem aprendizagens a partir de suas vivências e experiências, conforme o trecho:

\section{Quadro 2 - Trecho do relatório 3}

Após isto, foi utilizado o teodolito novamente. O aluno optou por calcular a altura da lâmpada da sala em um primeiro momento. Em seguida, o aluno sugeriu que calculássemos a altura de uma árvore. Deslocamos (sic) até o pátio da escola, onde levamos o teodolito e fita métrica. $O$ aluno mediu a distância do teodolito até a árvore para que pudesse aplicar a tangente do ângulo para descobrir a altura da árvore. O aluno não apresentou problemas nos cálculos numéricos [...] O aluno surpreendeu-me em vários momentos da aula, seja com cálculos sem o uso de papel ou com raciocínio lógico que ele possui.

Fonte: Arquivo pessoal.

A valorização da experiência no processo de construção do conhecimento tem sintonia com as ideias apresentadas por Maturana e Varela (2001), que afirmam "nossa experiência está indissoluvelmente atrelada à nossa estrutura" ou que os processos de viver e conhecer estão sempre relacionados. Segundo Pellanda (2009, p. 39): "não existe conhecimento sem experiência pessoal" ou que possa ser construído de forma separada dos processos de viver. Desse modo, mediar um processo apoiado por elementos cotidianos, a partir dos quais os estudantes poderão facilmente remeter à experiência, torna-se fundamental. Para além dessa questão, percebe-se uma busca constante, por parte do bolsista do PIBID, em apresentar atividades atrativas, lúdicas e que envolvessem os estudantes atendidos: 


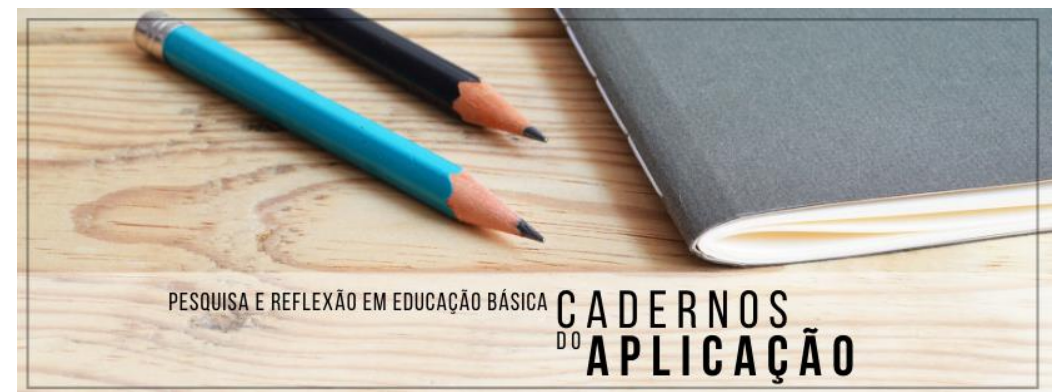

Cadernos do Aplicação

https://seer.ufrgs.br/CadernosdoAplicacao

Publicação Ahead of Print

ISSN 2595-4377 (online)

Porto Alegre | jul-dez. 2021 | v.34 | n.2

\section{Quadro 3 - Trecho do relatório 14 (R14) e do relatório 15 (R15)}

[...] propus uma atividade que envolvesse além de uma narrativa histórica e artística, aplicabilidade na sociedade e de conhecimento em geral. E assim, trabalhar com a interdisciplinaridade trazendo fatores históricos e artísticos, mas também fazer uma atividade dinâmica que envolvesse os alunos. No primeiro momento, apresentei o artista que fez a pintura. Os alunos demoraram um pouco, mas lembraram que se tratava do pintor Leonardo da Vinci. Então, nossa conversa começou em volta dele, trazendo curiosidades de Leonardo da Vinci, de como a Matemática era importante na vida dele. (R14)

No segundo momento, fomos para um jogo de "adivinha quem eu sou?" dando dicas sobre as propriedades e aparências dos sólidos, os alunos tinham que saber de qual sólido geométrico estava se referindo-se. (sic) Os alunos acharam bem engraçado, divertindo-se em realizar a atividade. Não apresentaram dificuldades quando apresentado (sic) a segunda dica de cada um desses objetos, apenas quando foi relacionado Tales [de Mileto] com pirâmides, mostrando-se um pouco confusos. Por fim, acredito que tais atividades fizeram os alunos compreender (sic) as diferenças entre área e volume de sólidos geométricos, mas também propor um momento descontraído com uma atividade em que os alunos puderam observar propriedades destes sólidos trabalhados na aula. (R15)

Fonte: Arquivo pessoal.

Os trechos apresentados indicam que as experiências construídas estão em sintonia com Paniago, Sarmento e Rocha (2018), onde entendemos que o fio condutor da prática pedagógica no atendimento educacional especializado tenha sido permeado por ações que envolviam diálogo e costura de ideias pelos membros envolvidos no projeto. O esquema abaixo, na Figura 1, procura ilustrar como as ações ocorriam no âmbito do projeto PIBID Matemática desde o conhecimento da demanda até a construção e publicação dos documentos inerentes ao projeto. 


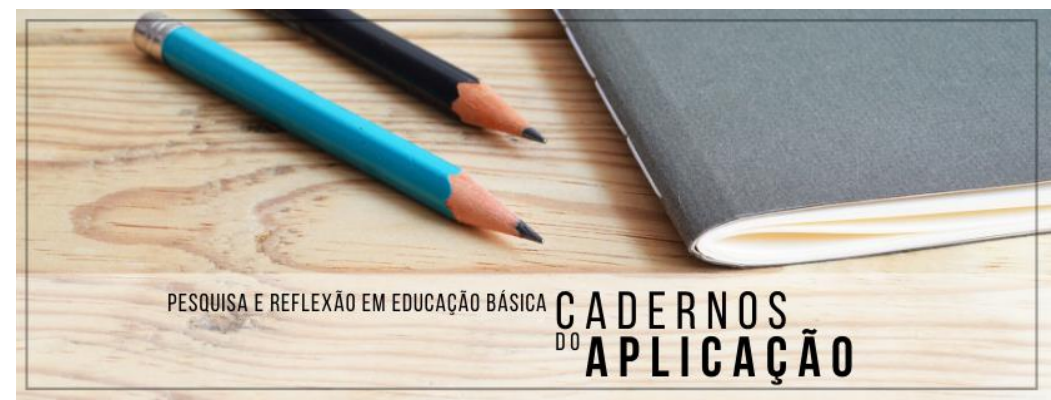

Cadernos do Aplicação

https://seer.ufrgs.br/CadernosdoAplicacao

Publicação Ahead of Print

ISSN 2595-4377 (online)

Porto Alegre | jul-dez. 2021 | v.34 | n.2

\section{Figura 1 - Fluxograma das ações realizadas no projeto PIBID Matemática}

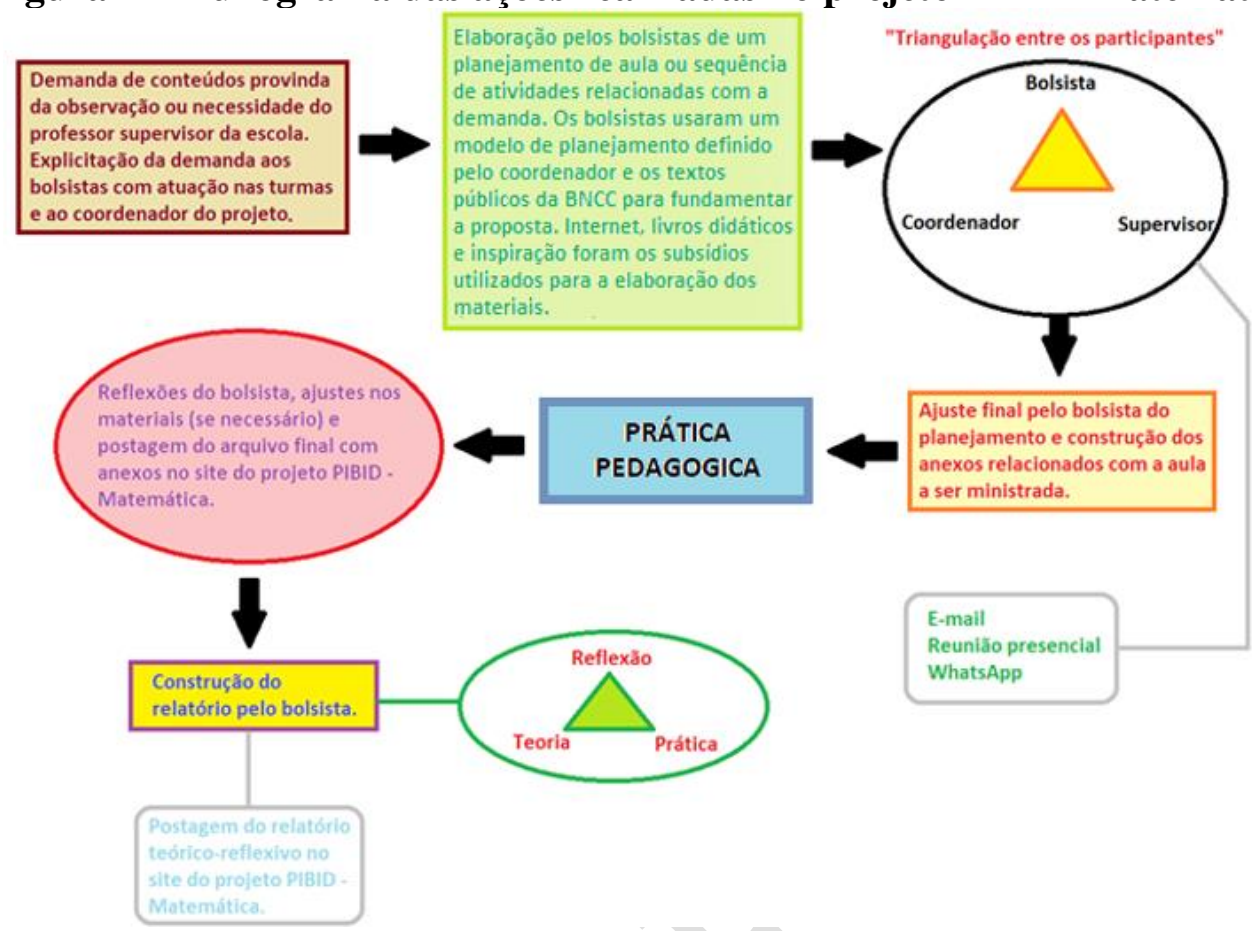

Fonte: Elaborado pelos autores.

Entendemos que esse conjunto de ações corrobora para uma formação docente decorrente da experiência, a qual foi construída, de forma prioritária, pela articulação entre teoria e reflexão sobre a prática. Uma formação que ocorre a partir da experiência é uma das temáticas centrais do projeto PIBID, sendo fundamental o diálogo, a troca entre professores e colegas e o planejamento, análise e construção de materiais didáticos. Nessa perspectiva, ressaltamos que a aprendizagem profissional da docência se torna possível através do PIBID, sendo relevante para a melhoria do trabalho de formação de professores por meio da reflexão sobre a própria prática. Trata-se de uma oportunidade de conhecer o contexto vivido diariamente no ambiente escolar e de compartilhar experiências, conhecimentos e ideias entre educadores, bolsistas, supervisores, orientadores e estudantes.

Os diálogos articulados com base em tais tessituras contribuem para a formação docente por meio da experiência, pois, a partir delas, as demandas e, consequentemente, um olhar de pesquisador podem ir se construindo ao longo das investigações e intervenções na escola. Essa formação docente que deriva da experiência também incorpora um aporte teórico que fomenta 


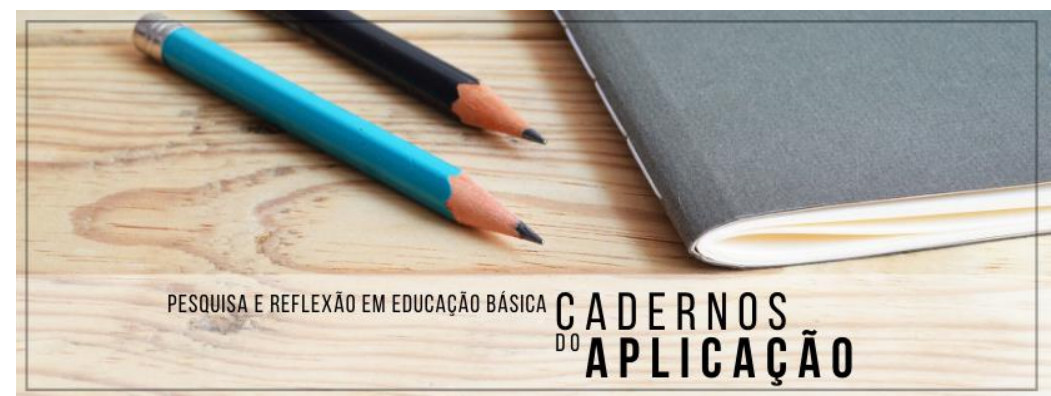

Cadernos do Aplicação https://seer.ufrgs.br/CadernosdoAplicacao

Publicação Ahead of Print

ISSN 2595-4377 (online)

Porto Alegre | jul-dez. 2021 | v.34 | n.2

tais trocas, diálogos e experiências vivenciados pelo docente, que agora é um professor naquilo que um dia também já foi estudante.

Nessa perspectiva, refletimos que o trabalho do PIBID se torna importante nessa conjuntura para além das questões que se relacionam à articulação entre a universidade e a escola de educação básica como primeira experiência, para o bolsista participante, na docência relacionada ao atendimento educacional especializado. A partir dessa primeira experiência, o bolsista se sente mais seguro para planejar suas aulas, pois já conhece algumas das possibilidades e desafios que se articulam à educação inclusiva, contribuindo não só para o professor, mas também para o aluno, assim como Pinto e Amaral (2019) afirmam:

As discussões sobre possibilidades e desafios da atuação docente perante uma educação escolar que favoreça a aprendizagem e o desenvolvimento dos alunos com deficiência, no âmbito da escola comum, precisam dar visibilidade às interações com o outro e à construção de significados e sentidos em torno das práticas pedagógicas. Para tanto, é importante considerar contextos sociais mais amplos e concepções de ensinar e aprender que embasem práticas pedagógicas desenvolvidas pelos professores, bem como o papel central da escola no desenvolvimento dos educandos (p. 4).

Torna-se necessário salientar a importância do investimento em programas de formação docente que considerem as temáticas relacionadas à Educação Especial e à inclusão escolar. Nossa percepção é que as grades curriculares oferecidas nas universidades contemplam essas questões ainda de forma tímida, tornando o programa de iniciação à docência (PIBID) um espaço para complementar essa formação. A formação de professores para a Educação Especial é uma necessidade emergente, visto o contexto de políticas que buscam ampliar a oferta e qualificá-la, na perspectiva da educação inclusiva, por meio da mediação em sala de aula e do atendimento educacional especializado.

Dessa forma, entendemos que a articulação contemplada neste texto, que envolveu diferentes participantes e ações do projeto PIBID Matemática, tornou-se essencial para o processo de formação de todos os docentes envolvidos. Não é possível, no entanto, afirmar que sentidos o projeto assumiu para cada um, tendo em vista a singularidade da experiência, mas é possível reiterar que os processos de formação inicial e continuada precisam considerar as práticas como espaços formativos emergentes ao percurso de futuros professores. Evocamos Borba (2020, p. 7), ao afirmar que "as práticas pedagógicas são fundamentais na trajetória de 


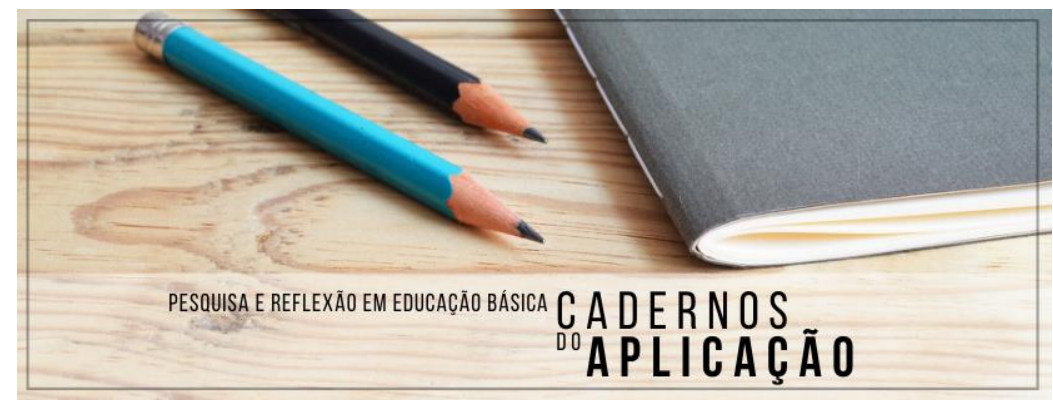

Cadernos do Aplicação

https://seer.ufrgs.br/CadernosdoAplicacao

Publicação Ahead of Print

ISSN 2595-4377 (online)

Porto Alegre | jul-dez. 2021 | v.34 | n.2

professores em formação", pois compreendemos que é a partir destas que se constitui o processo de formar-se docente.

O formar-se/tornar-se professor pode ter início na graduação, mas não é concluído ao término dela. É um processo longo, reflexivo e diário, que ocorre ao longo da docência, no cotidiano de atuação do professor, de forma dinâmica, como a vida, sendo fundamental que a prática e a teoria se constituam em relação (SILVA, 2015).

\section{Considerações finais}

A partir das discussões apresentadas, tornou-se possível perceber que o movimento formativo ocorre a partir da rede que se instituiu entre o grupo de professores envolvidos na proposta. Tal movimento ganha força na retomada do caderno de campo mantido pelo bolsista do PIBID e nos relatórios por ele elaborados. Ressalta-se que o movimento de escrever sobre a experiência com criticidade, estabelecendo reflexões e considerações acerca dos processos de aprendizagens dos alunos acompanhados no âmbito do atendimento educacional especializado, contribuiu para constituir o laço formativo. Compreendemos que as ideias que eram anunciadas de forma mais sintética no caderno de campo, ao tomarem um caráter analítico nos relatórios, possibilitaram a retomada do vivido, do experienciado, bem como uma reflexão, permitindo a constituição de um processo de formação.

Entendemos, ainda, que a partir da experiência vivenciada no âmbito do projeto PIBID, uma articulação entre a Matemática e a Educação Especial proporciona contribuições incomensuráveis no processo de formação inicial docente, pois todos se envolvem em um processo de construção formativo. Torna-se importante, nesse sentido, oferecermos destaque para a necessidade de um trabalho articulado entre o professor de Educação Especial e os demais professores (de outras áreas). Na presente investigação, o foco do processo formativo derivado da experiência envolveu professores da área de Matemática; no entanto, entendemos que seja fundamental um investimento cada vez mais qualificado em estudos que busquem analisar a potência do espaço de articulação entre o professor de Educação Especial e os demais docentes da escola regular. Uma das funções do professor responsável pelo atendimento educacional especializado envolve a articulação com os docentes da sala de aula regular e 


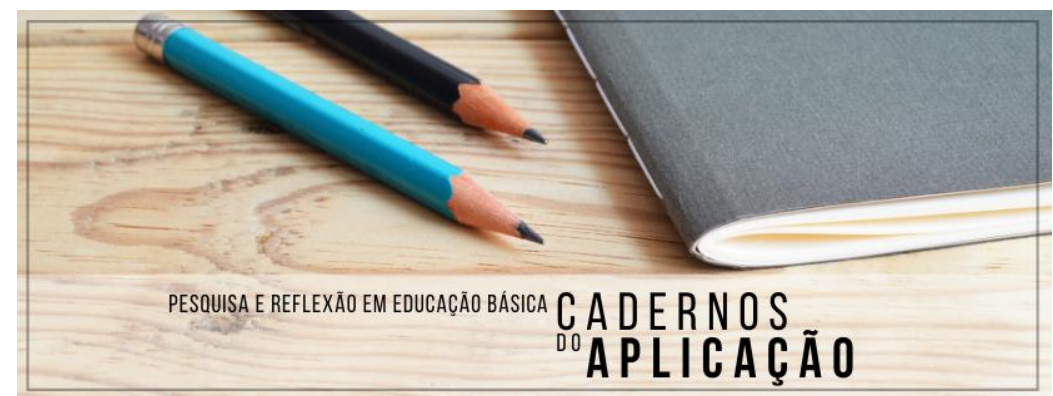

Cadernos do Aplicação https://seer.ufrgs.br/CadernosdoAplicacao

Publicação Ahead of Print

ISSN 2595-4377 (online)

Porto Alegre | jul-dez. 2021 | v.34 | n.2

apostamos na potência desse espaço de diálogo e na docência compartilhada como possibilidade para qualificar o processo inclusivo.

A proposta do PIBID constitui-se como uma oportunidade para a construção dessa articulação e, ao mesmo tempo, como um espaço para a formação docente. Assim, podemos destacar a importância do projeto, tendo em vista a possibilidade de aproximação com a docência feita por meio de orientação e acompanhamento dos futuros professores, bem como a pertinência do diálogo que surge na trama da rede das relações constituídas a partir das ações do projeto. Diante disso, reiteramos, por meio deste texto, a necessidade da manutenção de programas institucionais formativos como esse, que aproximam a escola de educação básica e a universidade, e a construção e manutenção de políticas de valorização da docência e da formação por meio da vivência de múltiplas experiências.

\section{Agradecimentos}

À Coordenação de Aperfeiçoamento de Pessoal de Nível Superior (CAPES) pelo recurso financeiro disponibilizado por meio do Edital n n 07/2018 para a execução do subprojeto PIBID Matemática, no âmbito da Universidade Federal do Rio Grande do Sul. Processo CAPES número: 88887.300983/2018-00.

\section{Referências}

BAPTISTA, Cláudio Roberto. Política pública, Educação Especial e escolarização no Brasil. Educação e Pesquisa, [S. 1.], v. 45, p. e217423, 2019. DOI: 10.1590/s16784634201945217423. Disponível em: https://www.revistas.usp.br/ep/article/view/163912. Acesso em: 9 ago. 2021.

BOGDAN, Robert; BIKLEN, Sari. Investigação qualitativa em educação: uma introdução à teoria e aos métodos. Porto: Porto Ed. 1994.

BORBA, Bruna Barros de. Os processos de aprendizagem e o Transtorno do Espectro do Autismo (TEA): do segundo ao terceiro ano do ensino fundamental. Cadernos do Aplicação,

Porto Alegre, jul-dez., v.33, n.2, 2020. Disponível em: https://seer.ufrgs.br/CadernosdoAplicacao/article/view/98853/60962. Acesso em: 9 ago. 2021.

BRASIL. Ministério da Educação. Política Nacional de Educação Especial na perspectiva da Educação Inclusiva. MEC/SEESP. Brasília: 2008. 


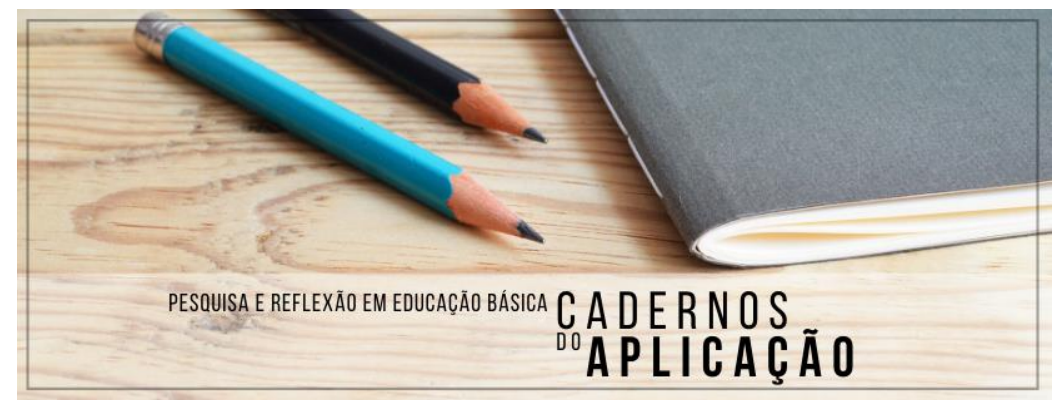

Cadernos do Aplicação https://seer.ufrgs.br/CadernosdoAplicacao

Publicação Ahead of Print

ISSN 2595-4377 (online)

Porto Alegre | jul-dez. 2021 | v.34 | n.2

Ministério da Educação. Resolução CNE/CEB No 4, de 2 de outubro de 2009. Institui Diretrizes Operacionais para o Atendimento Educacional Especializado na Educação Básica, modalidade Educação Especial. MEC/SEESP, 2009.

Lei $n^{\circ}$ 13.146, de 6 de julho de 2015. Institui a Lei Brasileira de Inclusão da Pessoa com Deficiência (Estatuto da Pessoa com Deficiência). Diário Oficial da União, Brasília-DF Seção 1, 7 de julho de 2015, p. 2. 2015.

CAVALCANTE, Maria Mikaele Silva; SANTOS, Maria Adriana Borges; SILVA, Silvina Pimentel, FERREIRA, Heraldo Simões. PIBID como experiência de formação: perspectivas de professores supervisores. Educação: Teoria e Prática, Rio Claro, SP. v. 29, n.61, p. 389-403. 2019. Disponível em: https://doi.org/10.18675/1981-8106.vol29.n61.p389-403. Acesso em: 12 out. 2020 .

HONNEF, Cláucia; COSTAS, Fabiane Adela Tonetto. Formação docente para a educação especial na perspectiva inclusiva: o papel das experiências pedagógicas nesse processo. Reflexão e Ação, Santa Cruz do Sul, v. 20, n. 1, p. 111-124, jul. 2012. ISSN 1982-9949. Disponível em: doi: https://doi.org/10.17058/rea.v20i1.2359. Acesso em: 5 jul. 2021.

IMBERNÓN, Francisco. La ivestigación sobre y com el profesorado. La repercusión em la formación del profesorado. ¿còmo se investiga? Redie, México, v. 14, n. 2, 2012, p. 1-9. Disponível em: https://redie.uabc.mx/redie/article/view/300. Acesso em: 9 ago. 2021.

LIMA, Francisca Cícera de; JERÔNIMO, Rita Carolina Gondim da Fonseca; GOUVEIA, Luciana de Freitas Patriota. Educação Inclusiva: os desafios da formação e as dificuldades na atuação docente. Brazilian Journal of Development, Curitiba, v.6, n.10, p.79580-79591, 2020. Disponível em: https://doi.org/10.34117/bjdv6n10-402. Acesso em: 6 fev. 2021..

MATURANA, Humberto; VARELA, Francisco Javier. A árvore do conhecimento: as bases biológicas da compreensão humana. São Paulo: Palas Athena, 2001.

PANIAGO, Rosenilde Nogueira; SARMENTO, Teresa. A formação na e para a pesquisa no Pibid; possibilidades e fragilidades. Educação \& Realidade, Porto Alegre, v. 42, n. 2, p. 771792. 2017. Disponível em: https://seer.ufrgs.br/educacaoerealidade/article/view/58411. Acesso em: 10 ago. 2021.

PANIAGO, Rosenilde Nogueira; SARMENTO, Teresa; ROCHA, Simone Albuquerque da. O PIBID e a inserção à docência: experiências, possibilidades e dilemas. Educ. rev., Belo Horizonte, $\quad$ v. 34, e190935, 2018. Disponível em http://www.scielo.br/scielo.php?script=sci_arttext\&pid=S0102-46982018000100176. Acesso 10 nov. de 2020.

PELLANDA, Nize Maria Campos. Maturana e a educação. Belo Horizonte: Autêntica, 2009. 


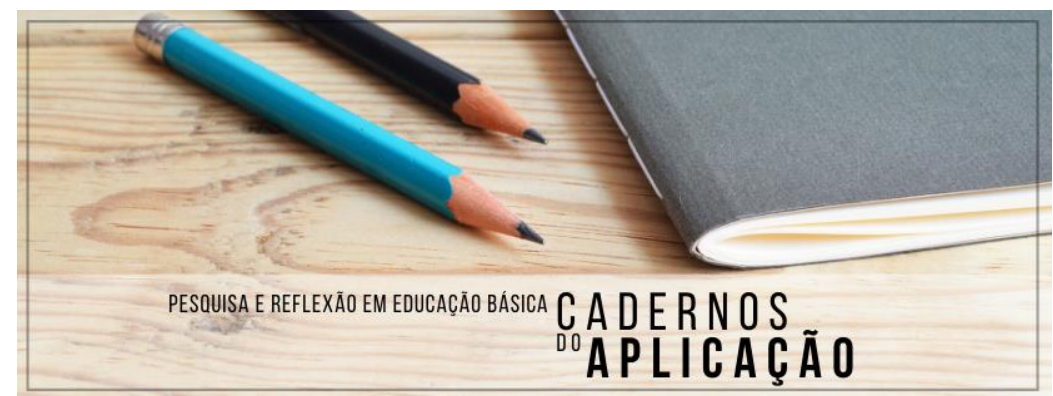

Cadernos do Aplicação https://seer.ufrgs.br/CadernosdoAplicacao

Publicação Ahead of Print

ISSN 2595-4377 (online)

Porto Alegre | jul-dez. 2021 | v.34 | n.2

PETRÓ, Caroline da Silva. A inclusão escolar de alunos com deficiência visual a partir da percepção de professores de matemática, professores do atendimento educacional especializado e gestores educacionais. 2014. 93 f. Dissertação (Mestrado em Ciências e Matemática) - Pontifícia Universidade Católica do Rio Grande do Sul, Porto Alegre, 2014. Disponível em: http://tede2.pucrs.br/tede2/handle/tede/3474. Acesso em: 5 jul. 2021.

PINTO, Gláucia Uliana; AMARAL, Mateus Henrique do. Formação docente continuada e práticas de ensino no atendimento educacional especializado. Pro-Posições, Campinas, v. 30, e20180032, 2019. Disponível em: https://doi.org/10.1590/1980-6248-2018-0032. Acesso em: 5 nov. de 2020.

ROSSETTO, Elisabeth. Formação do professor do atendimento educacional especializado: a Educação Especial em questão. Revista Educação Especial, Santa Maria, p. 103-116, dez. 2015. ISSN 1984-686X. Disponível em: http://dx.doi.org/10.5902/1984686X13367. Acesso em: 5 jul. 2021.

ROSA, Thaylles Leal da; SILVA, Mayara Costa da; SILVA, Rodrigo Sychocki da. Projeto PIBID e Atendimento Educacional Especializado: uma experiência com o uso de jogos e materiais concretos na construção de conceitos de Matemática pelos estudantes. REMAT: Revista Eletrônica da Matemática, v. 6, n. 2, p. e2001, 28 jul. 2020. Disponível em: https://doi.org/10.35819/remat2020v6i2id3965. Acesso em: 5 ago. 2021.

SILVA, Mayara Costa da. Formação de Professores e Educação Especial: a experiência como constitutiva do formar-se. 2015. 125 f. Dissertação (Mestrado em Educação). Faculdade de Educação, Universidade Federal do Rio Grande do Sul, 2015. Disponível em: https://lume.ufrgs.br/handle/10183/128922. Acesso em: 9 ago. 2021.

SILVA, Margaret do Rosário Silva. Dificuldades enfrentadas pelos professores na educação inclusiva. 2011. vii, 54 f. Monografia (Especialização em Desenvolvimento Humano, Educação e Inclusão Escolar). Universidade de Brasília, Universidade Aberta do Brasil, Brasília, 2011. Disponível em: https://bdm.unb.br/handle/10483/2487. Acesso em: 6 fev. 2021.

TARDIF, Maurice. Saberes docentes e formação profissional. Petrópolis: Vozes, 2013.

TAVARES, Lídia Mara Fernandes Lopes; SANTOS, Larissa Medeiros Marinho dos; FREITAS, Maria Nivalda Carvalho. A Educação Inclusiva: um Estudo sobre a Formação Docente. Rev. bras. educ. espec., Marília, v. 22, n. 4, p. 527-542, 2016. Disponível em: https://doi.org/10.1590/s1413-65382216000400005. Acesso em: 6 fev. 2021.

VASCONCELlOS, Maria José Esteves de. Pensamento Sistêmico: O Novo Paradigma da Ciência, Campinas, SP: Papirus, 2012.

Data de submissão: $15 / 05 / 2021$

Data de aceite: 10/08/2021

DOI: https://doi.org/10.22456/2595-4377.116851 